\title{
The role of the TGF-SMAD signalling pathway in the etiopathogenesis of severe asthma
}

The authors declare no financial disclosure

\begin{abstract}
Asthma is a chronic inflammatory heterogeneous disease of the lower respiratory tract characterised by the occurrence of bronchial hyper-responsiveness and paroxysmal, changeable bronchial obstruction. Transforming growth factor-beta (TGF- $\beta$ ) is one of the cytokines involved in mediating airway inflammation and remodelling. The level of TGF- $\beta 1$ gene expression correlates with severity of symptoms. Alterations in the main SMAD signal transmission, overexpression of TGF- $\beta$ genes and changes in the transcriptome cause excessive secretion of TGF- $\beta$ and its increased expression in target cells, which clinically induces a moderate-severe or severe course of asthma as well as an earlier and faster disease progression. Knowledge of these processes allows clinicians to assess immune responses in patients, which affects adequate disease control and prevention of remodelling.
\end{abstract}

Keywords: transforming growth factor $\beta$ TGF- $\beta$, signalling proteins SMAD, remodelling; severe asthma

Pneumonol Alergol Pol 2016; 84: 290-301

\section{Introduction}

in the context of understanding the heterogeneous pathogenesis and development of asthma, a special attention of researchers has been focused on the transforming growth factor beta (TGF- $\beta$ ). Although nowadays five types of isoforms of this factor have been identified, there are only three isoforms found in the human body (TGF- $\beta 1$, TGF- $\beta 2$, TGF- $\beta 3$ ), each one coded by separate genes. Depending on a type of tissue, a proper isoform and its concentration, they affect the processes of synthesis, proliferation, differentiation, and apoptosis of the extracellular matrix components and the maintenance of appropriate homeostasis of the human organism [1].

\section{TGF- $\beta$ superfamily}

TGF- $\beta$ superfamily is an evolutionarily highly conserved superfamily of proteins, already pres- ent in Drosophila sp., in which the expression of genes associated with TGF- $\beta$ influences the formation of organ structures in early embryogenesis and communication between particular tissues in their later development. The superfamily of TGF- $\beta$ is divided into three subfamilies according to the similarity of sequences and specific signalling pathways, which activate the first subfamily including the transforming growth factor beta (TGF- $\beta$ ) and activins. The second subfamily is represented by the secretory protein synthesized in cells of the nodal growth differentiation factor (NODAL) and the glial cell derived neurotrophic factor (GDNF). The third one comprises bone morphogenetic proteins (BMPs), growth differentiation factors (GDFs) and anti-mullerian hormone (AMH) $[2,3]$.

\section{Molecular Structure}

A dimeric molecule is an active form of TGF- $\beta$ whose monomers consist of a few $\beta$ strands

Address for correspondence: Marcelina Koćwin,Department of Internal Medicine, Asthma and Allergy of The Medical University of Lodz, N. Barlicki University Hospital No. 1 of Medical University of Lodz, ul. 22 Kopcinskiego, 90-153 Łódź, tel.: +4842677 69 50, fax: +48 42 6781176, e-mail: marcelina.kocwin@gmail.com

DOl: 10.5603/PiAP.2016.0037

Received: 10.04.2016

Copyright (C) 2016 PTChP

ISSN 0867-7077 
spatially arranged by three disulphide bonds in a cysteine knot structure. Hydrophobic bonds and disulphide bridges stabilize a dimeric molecule and its arrangement affects subsequent formation of complexes with one of two types of receptors for TGF- $\beta[4]$.

\section{Mapping and promoters}

There are three various isoforms of the transforming growth factor in the human body, which are localized on chromosomes TGF- $\beta 1-19 \mathrm{q} 13$, TGF- $\beta 2-1 \mathrm{q} 41$ and TGF- $\beta 3-14 \mathrm{q} 24$, respectively, whose regulation occurs at the transcriptional level [5]. A promoter for TGF- $\beta 2$ and TGF- $\beta 3$ isoforms possesses in its structure a classical TATAA box domain and a CRE-ATF terminal region that are subject to hormonal control [6, 7]. However, the promoter for TGF- $\beta 1$ does not contain the TATAA box, but has a sequence of regulatory sites capable of activation due to proto-oncogenes, such as $c$-jun, $c$-fos or egr-1, and also oncogenes $a b l$, fos, jun, ras and src [8]. This enables TGF- $\beta$ promoter's activity to be inhibited by tumour suppressor genes and the products of expression of retinoblastoma or Wilms' tumour genes.

Each gene of particular isoform codes for a pre-pro-peptide, which undergoes division into two peptides by furin-like protease in the Golgi apparatus. A $24 \mathrm{kDa}$-homodimer of the mature TGF- $\beta$ is non-covalently bound to $80 \mathrm{kDa}$-latency-associated peptide (LAP) forming a small latent complex (latent TGF $\beta$-binding protein LTGF- $\beta$ ) [9]. The essential role of this complex is to transport TGF- $\beta$ to the extracellular matrix. TGF- $\beta$ included in the latent complex lacks the ability to bind to its receptors, which is affected by various factors, such as fluctuations of temperature and $\mathrm{pH}$, ionizing radiation, and thrombospondins or plasmins. The junction of TGF- $\beta$, pro-peptide dimer and LTGF- $\beta$ is called a large latent complex (LLC) [10].

\section{Cytokine function}

\section{TGF- $\beta 1$}

The best recognized isoform is a highly pleiotropic cytokine of TGF- $\beta 1$ located on chromosome 19q13, and expressed in endothelial, hematopoietic and connective tissue cells. It is synthesized in the human body by activated $\mathrm{T}$ and $\mathrm{B}$ lymphocytes, macrophages, platelets and neutrophils [11]. TGF- $\beta 1$ activity has so far been regarded as anti-inflammatory, it has been stated that its activity may be also pro-inflammatory $[12,13]$. TGF- $\beta 1$ has immunosuppressive effects on T and B lymphocytes, and NK cells as well as inhibits expression of MHC class II antigens [14]. A deficiency or total lack of this cytokine may predispose people to more frequent manifestation of autoaggressive diseases such as systemic lupus or systemic sclerosis $[15,16]$. TGF- $\beta 1$ also plays a role in the pathogenesis of vascular inflammatory states in atheromatosis and vascular changes in the Alzheimer disease, articular inflammations, and hepatic cirrhosis associated with the HCV infection or progression of diabetic nephropathy [17].

A special role is ascribed to the TGF- $\beta 1$ cytokine in the pathogenesis and development of allergic diseases, particularly bronchial asthma. This is connected with the ability to induce chemoattractive activity of fibroblasts, stimulate their proliferation, and increase the synthesis of fibroblasts, fibronectin, proteoglycans and type I and III collagen, as well as to inhibit gene expression of collagenases and matrix metalloproteinases. The cytokine level significantly increases in the course of bronchial asthma $[18,19]$. Moreover, the release of TGF- $\beta 1$ by eosinophils in the submucosa of bronchial airways is favoured by a series of environmental factors such as common inhaled allergens or tobacco smoke. Hence, a closer examination is required of the correlations between the level of asthma intensity and development and the occurrence of inhaled allergy or long-term smoking in patients [20]. Experimental studies performed in various international research centres revealed an increased TGF- $\beta 1$ gene expression, with simultaneously reduced eosinophil migration to the inflammatory focus in the airways of tobacco smokers [21]. The degree of inflammatory reaction intensity depends on individual sensitivity as well as on genetic components. Genes directly associated with the onset of the pathological process are thought to be genes involved in the regulation of the IgE level and those affecting individual bronchial hyper-reactivity. Genes regulating the development and maintenance of chronic inflammation, airway remodelling and the response to treatment with particular consideration to glucocorticosteroids are responsible for severity of the disease [22]. One of the genes whose expression level correlates with a degree of severity of asthma symptoms is the TGF- $\beta 1$ gene [23, 24]. In control group patients with mild, moderate to severe, and severe course of asthma, four polymorphic forms of the promoter region (C-509T, 72insC, T869C and G915C) were observed [25]. A significant role was played by C-509T, in which a single nucleotide polymorphism (C/T at position 509) caused 
the formation of YY1-binding site - a probable new site for binding transcription factors. In practice, it is manifested by the elevated serum TGF- $\beta 1$ cytokine and IgE levels [26]. Patients homozygous for 509T allele usually produced a haplotype 1, occurring in the majority of groups with moderate to severe and severe symptoms, as compared to the group of controls and patients with mild asthma. It has been proven that people with a haplotype 1 were also homozygous for $72 \mathrm{C}$, 869C, and 915C variants [25, 27]. The study of a haplotype variant as a risk factor for disease severity may help in prognosing asthma development in a particular patient. Moreover, the presence of the four single nucleotide polymorphisms (SNPs-509T, 72C, 869C and 915C) correlates with an increased predisposition to atopy [28].

\section{TGF- $\beta 2$}

TGF- $\beta 2$ isoform is predominantly produced in the nerve and epithelial cells. TGF- $\beta 2$ has been mapped to chromosome 1q41. Its expression is seen at the level of embryogenesis in such tissues as the epithelium of bronchi, auditory meatus, lenses, and retina or mesenchyme, as well as in precartilaginous blastema and a later growth zone of long bone, which indicates the effect of TGF- $\beta 2$ on skeletal formation [29,30]. Its overexpression is especially visible in diseases with matrix fibrosis such as bronchial asthma, optic nerve hypoplasia, or primary open-angle glaucoma [31, 32]. TGF- $\beta 2$ is also subject to a strong expression in various cancer cell lines, which is associated with the promotion of cancer cell survival through the activation of a nuclear factor kappa B (NF$\kappa \mathrm{B})$. Its effect on the development of ovarian and prostate cancer or glioblastoma multiforme has been evidenced, and its ability to degrade the extracellular matrix favours migration and invasion of tumour cells. TGF- $\beta 2$ is regarded as an important cytokine in the process of embryonic morphogenesis, and a reduced TGF- $\beta 2$ gene expression leads to developmental disorders concerning mainly facial skeleton, organs of vision and hearing, vertebral column or cardiovascular system [33]. TGF- $\beta 2$ overexpression is more often observed in the case of congenital and acquired structural defects as well as in cardiac valve fibrosis, sporadically in Fallot's tetralogy, while loss of heterozygosity (LOH) in the TGF- $\beta 2$ gene is associated with a more frequent occurrence of symptomatic aortic aneurysm originated by histopathological changes in a form of fragmentation of elastin fibres and excessive collagen and proteoglycan deposition, also observed in the pathogenesis of bronchial asthma [34]. Multifold higher levels of this cytokine were detected in respiratory tract biopsies obtained from asthma patients as compared to healthy subjects. Moreover, in the biopsy material from asthma patients, the TGF- $\beta 2$ level was found to be higher than that of TGF- $\beta 1$. The TGF- $\beta 2$ involvement in airway remodelling correlates with an increase in mucin expression in bronchial epithelial cells [35]. There are some hypotheses that interleukin 13 (IL-13) produced in excessive amount by Th2 lymphocytes, eosinophils and NK cells may increase the TGF- $\beta 2$ secretion through epithelial cells $[36,37]$. A significant increase in TGF- $\beta 2$ positive eosinophils and macrophages was also observed in immunohistochemical staining of the bronchial epithelium from patients with moderate and severe asthma after the allergen challenge, whereas bronchoalveolar lavage (BAL) revealed an increase in the level of both TGF- $\beta$ isoforms in the bronchial epithelium of those patients [38].

\section{TGF- $\beta 3$}

The third TGF- $\beta$ isoform (TGF- $\beta 3$ ), whose gene is located on chromosome $14 \mathrm{q} 24$, undergoes expression especially in mesenchymal tissues, which can affect proliferation and differentiation of primary cells of internal organs, bronchial epithelium, aortic intima endothelium, as well as perichondrium and chondroblasts involved in the formation of primary embryonic skeleton [39]. It has been proven that lack of this isoform can lead to developmental defects of palate and lungs. TGF- $\beta 3$ with TGF- $\beta 1$ induces the expression of fibroblast growth factors, and TGF- $\beta 3$ alone exerts a great impact on fibroblast proliferation [14].

Cytokines from the TGF- $\beta$ family participate in the maturation and secretion of pituitary gland secretory cells. TGF- $\beta 3$ released by lactotrophic cells in adequate amounts stimulates the function of folliculotrophic cells that reversibly stimulate lactotrophic cells, which is regarded as one of the mechanisms promoting TGF- $\beta 3$ involvement in developing prolactinoma. TGF- $\beta 3$ and TGF- $\beta 2$ isoforms occur in glial and microglial cells, as well as in astrocytes and oligodendrocytes [40]. Moreover, TGF- $\beta 3$ is an important regulator of neuron differentiation, a neurite stimulator and cofactor of neurotrophic factors, e.g. a glial cell-derived neurotrophic factor (GDNF), neurotrophins (NT), ciliary neurotrophic factor (CNTF), or fibroblast growth factor 2 (FGF 2), and is extremely promising for use in regeneration of neurons in culture [41] (Table 1). 
Table 1. Localization of the expression of mRNA coding TGF- $\beta 1-3$ isoforms

\begin{tabular}{|c|c|c|c|}
\hline $\begin{array}{l}\text { Localization of the expres- } \\
\text { sion of mRNA coding TGF- } \beta \\
1-3\end{array}$ & $\begin{array}{c}\text { Isoform } \\
\beta 1\end{array}$ & $\begin{array}{c}\text { Isoform } \\
\beta 2\end{array}$ & $\begin{array}{c}\text { Isoform } \\
\beta 3\end{array}$ \\
\hline Hematopoietic tissue & + & - & - \\
\hline \multicolumn{4}{|l|}{ Epithelia } \\
\hline - bronchi & + & $\begin{array}{l}+ \text { (squ- } \\
\text { amous } \\
\text { epithe- } \\
\text { lium) }\end{array}$ & $\begin{array}{l}+ \text { (cu- } \\
\text { boidal } \\
\text { epithe- } \\
\text { lium) }\end{array}$ \\
\hline - salivary glands & + & + & - \\
\hline - suprabasal keratinocytes & - & + & - \\
\hline - otic epithelium & - & + & - \\
\hline- lens & - & + & - \\
\hline - retina & - & + & - \\
\hline - olfactory epithelium & - & + & - \\
\hline Immature epidermis & - & - & - \\
\hline \multicolumn{4}{|l|}{ Cartilage and bone } \\
\hline - precartilaginous blastema & - & + & + \\
\hline - growth zone of long bone & - & + & - \\
\hline - perichondria & - & - & + \\
\hline - osteoblasts & + & - & - \\
\hline - osteoclasts & + & - & - \\
\hline \multicolumn{4}{|l|}{ Cardiovascular tissue } \\
\hline - pre-valvular endothelium & + & - & - \\
\hline - myocardium & + & - & - \\
\hline - aortic intima & - & + & - \\
\hline \multicolumn{4}{|l|}{ Endocrine system } \\
\hline - thyroid gland & + & - & - \\
\hline - parathyroid glands & + & - & - \\
\hline - thymus & + & - & - \\
\hline \multicolumn{4}{|l|}{ Neuronal tissue } \\
\hline - ventral spinal cord & - & + & - \\
\hline Mesothelium & - & - & + \\
\hline Mesenchyme & - & + & + \\
\hline
\end{tabular}

TGF- $\beta$ s are pleiotrophic compounds produced by the majority of fibroblastic or epithelial cells. They stimulate proliferation of chondroblasts, osteoblasts, and neuronal tissue cells. TGF- $\beta$ s are growth inhibitors for epidermal, endothelial, hematopoietic cells and for some types of mesenchymatic cells [42]. Due to multidirectional activity, they must be subject to precise regulation - loss of control over their activity at each stage of the individual development may lead to induction of various diseases including neoplasms. They combine properties of growth factors and cytokines, for which they use specific receptors that transmit signals, two of them with serine-threonine kinase activity (TGF- $\beta$ RI and TGF- $\beta$ RII) and the third one (TGF- $\beta$ RIII) without any enzymatic activity.

\section{TGF-SMAD signaling pathway}

\section{SMAD family}

Involvement of two types of membrane receptors and mediating proteins from the SMAD family is necessary for the transduction of TGF- $\beta$ into the inside of the cell. The name of this family is derived from two homologous Sma proteins occurring in Caenorhabditis elegans and Mad present in Drosophila melanogaster [43].

The SMAD protein family is divided into three groups: proteins activated by the

R-SMAD receptor to which SMAD 1,2,3,5,8 belong; Co-SMAD, the protein co-mediating Smad4; and the third group, the inhibitory I-SMAD proteins with representatives SMAD 6,7 [44].

R-SMAD proteins are responsible for transmitting a signal into the cell nucleus. Structurally, they consist of MH domains (homology with the Drosophila protein Mad) separated from each other by a binding element. The N-terminal domain is responsible for binding to DNA, while the C-terminal domain interacts with other proteins. Inactive forms of R-SMAD can be found in the cell cytoplasm [45].

The second subtype of SMAD proteins is a mediating protein Co-SMAD, whose the only representative is SMAD 4. It participates in the formation of a complex with phosphorylated R-SMAD proteins, enabling them to penetrate into the cell nucleus from the cytoplasm.

There is the third type of proteins, inhibitory (I-SMAD) SMAD 6,7, in the cell nucleus. Their structure differs from the first group of the protein superfamily: they consist only of the C-terminal domain, without the N-terminal domain [44].

\section{TGF- $\beta$ receptors}

Three types of membrane receptors are found in the cell membrane: type I receptor (TGFR-II), type II (TGFR-II) and type III (TGFR-III).

A type I receptor (TGFR-II) (called a type Alk receptor) is a glycoprotein with a molecular mass of $53 \mathrm{kDa}$. There are seven subgroups from Alk1 to Alk7. TGF- $\beta$ mainly acts through three types of receptors: Alk1 - occurring in endothelium; Alk2 - in cells of the cardiovascular system and in the ventral portion of mesoderm during 


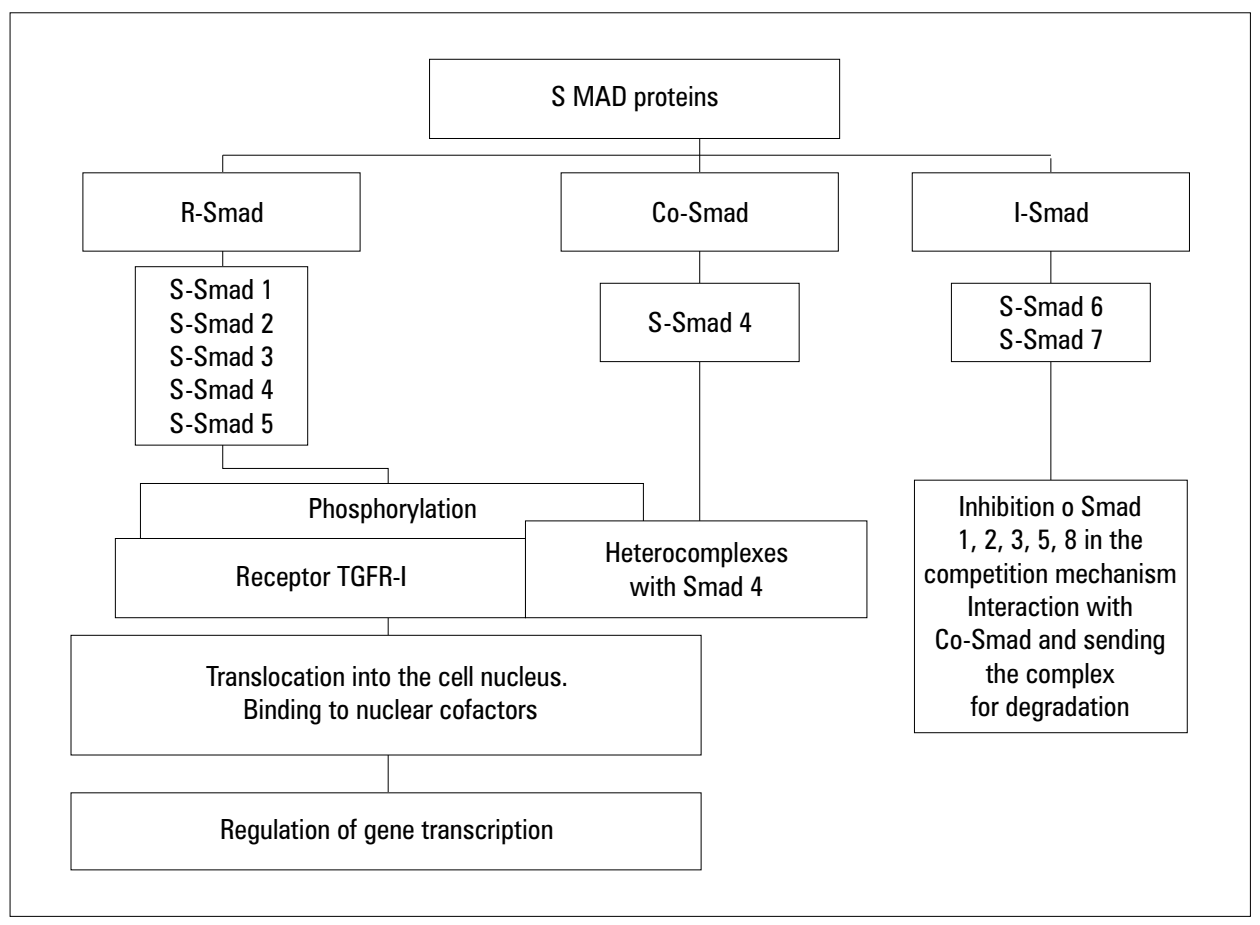

Figure 1. Regulation of gene transcription through SMAD signaling pathway

embryogenesis [46]; and the most important Alk7 - located in fibroblasts, skeletal progenitor cells, osteoblasts, chondroblasts and perichondrium [47]. The remaining subtypes Alk 3,4,6 are activated particularly by bone morphogenetic proteins (BMP) [48].

A type I receptor consists of a domain with a protein serine/threonine kinase activity in the transmembrane region and the ligand-binding domain. The glycine/serine-rich domain (GS) (amino acid sequence SGSGSG) occurs outside the membrane [49].

A TGFR-II receptor is a glycoprotein with a molecular mass of $85-110 \mathrm{kDa}$ made up of the $\mathrm{N}$-terminal ligand-binding domain, transmembrane region and C-terminal domain with a protein serine/threonine kinase activity [50].

TGF- $\beta$ exhibits a high affinity for the type II receptor and lack of affinity for the type I receptor. Ligands initially bind to TGFR-II. A large ligand-receptor complex is formed, which consists of a TGF- $\beta$ protein dimer and two molecules of the TGFR-II receptor as well as of two TGFR-II molecules. This binding enables serine and threonine residues to be phosphorylated in the GS domain of the TGFR-II receptor through type II, which causes their activation [51].

\section{Signalling pathway}

Secondary signalling molecules, i.e. R-SMAD proteins (SMAD proteins regulated by the recep- tor) or a protein of another pathway, i.e. chaperone one (ShcA), bind to the activated TGFR-II receptor.

A type III receptor with a molecular mass of $280-330 \mathrm{kDa}$, enhances the ligand's access to type I and type II receptors [2].

TGF- $\beta$ pathway depends on SMAD proteins. SMAD2 and SMAD3 form complexes with TGFR-II and activin receptors (ActR). SMAD 1, 5 and 8 are recognized by the bone morphogenetic protein receptor (BMPR) [52]. R-SMAD proteins bind to a mutual comediator SMAD4, binding both signal transmission pathways by TGFR and BMPR receptors. SMAD6 and 7 play a role of inhibitors of the following interactions: 1) TGFR-II-R-SMAD and 2) R-SMAD-Co-SMAD. Interaction between the kinase domain of the TGFR-II receptor and the conservative region of the C-terminal SMAD protein (MH2 domain) is highly specific [53].

The active TGFR-II receptor stimulates R-SMAD 2 or 3 protein phosphorylation within the serine residues in the conservative $\mathrm{SS}(\mathrm{M} / \mathrm{V})$ $\mathrm{S}$ motif in the C-terminal region. R-SMAD 2 and 3 are bound to the endosomal protein, SMAD anchor for receptor activation (SARA). A heterodimer of the R-SMAD phosphorylated protein with the Co-SMAD protein is formed. Next, this complex is transported into the cell nucleus, however the mechanism of this nucleo-cytoplasmic transport has not been completely elucidated to date. This complex binds through the MH1 
domain in the cell nucleus to CAGAC sequences (SMAD-binding domain - SBD) or with GC rich sequences in numerous gene promoter regions [54]. SMAD proteins interact with complexes remodelling chromatin (SWI/SNF) and with a DNA demethylating protein complex (DNA demethylase - DNDM) [55]. Moreover, SMAD proteins exert impact on regulation of gene transcription in the cell nucleus: they induce the transcription through the activation of histone acetyltransferases (HAT) p300, CBP, GCN5 or inhibit gene transcription through the recruitment of histone deacetylases (HDAC), e.g. RBL1 [56].

Free SMAD proteins are characterized by low specificity to bind to DNA, therefore they must interact with each other and with factors being able to bind to DNA. Selective activity of SMAD proteins is owed to the interaction with transcriptive factors such as AP-1, ETS, C/EBP $\beta$, FoxH1 and FoxO [57].

Signal transmission along the SMAD pathway may be modified at each level due to phosphorylation, ubiquitylation or ADP-ribosylation [58]. The way of enzymatic inhibition of SMAD activity in the cell nucleus is the following, as shown on Figure 2.

Inhibition of SMAD activity may be also achieved by inhibitory proteins SMAD7, which induce degradation of the TGFR-II receptor, inhibit R-SMAD phosphorylation and form a R-SMAD-Co-SMAD complex. I-SMAD proteins competing with R-SMAD for binding to the receptor or SMAD4 prevent signal transmission by TGF- $\beta$ [59]. Furthermore, SMAD7 is also involved in the recruitment of SMURF2 ubiquitin ligase to TGF- $\beta$ receptors, which leads to proteolytic and lysosomal degradation of TGFR-II-TGFR-II complexes, and Smad7 and Smad2 [60].

Factors inhibiting SMAD include corepressors, such as nuclear oncoproteins, c-SKI and c-SNO, which prevent formation of active R-SMAD-Co-SMAD complexes [61].

Completion of the process of signal transmission takes place through dephosphorylation of active R-SMAD proteins with the involvement of a specific phosphatase and through their ubiquitination and degradation in proteasome with coparticipation of SMAD7. SMADs are thought to be also involved in the control of the expression of $C D K N 2 B$ gene encoding p15, and CDKN1A gene encoding p21, c-myc, ID1 and ATF3 [62].

Part of proteins involved in DNA binding to SMADs is tissue specific. In respiratory diseases, blocking of the inhibitor of DNA-binding 1 (ID-1) expression in epithelial cells through

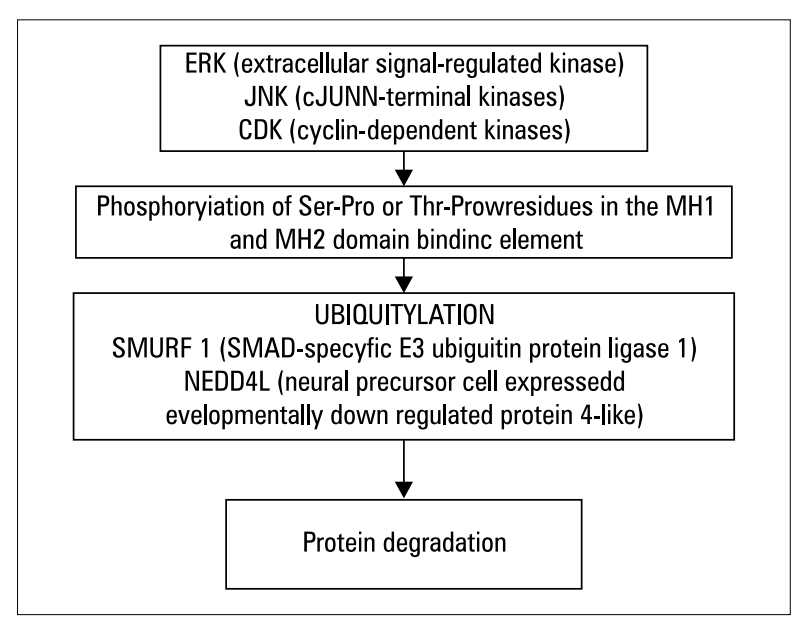

Figure 2. Modifications of signal transmission along SMAD pathway

formation of a complex with a corepressor of transcriptional activation factor 3 (ATF-3) seems to be significant [63].

Binding to various DNA-binding cofactors and involvement in numerous signalling pathways influence the SMAD-binding to gene promoter regions, which have an impact on diversity of transcription responses in respective cells.

The main TGF- $\beta$-mediated signal transmission occurs with the involvement of SMADs. However, there are alternative pathways, in which the involvement of mitogen activated protein kinases (MAPK): JUN N-terminal kinase (JNK), extracellular signal-regulated kinases (ERK1 and ERK2), p38 and phosphoinositide-3-kinase (PI3K)'is postulated. Moreover, the TGF- $\beta$ effect on signalling of the transcription nuclear factor kappa B (NF- $\kappa \mathrm{B})$ has been shown. The main NF- $\kappa \mathrm{B}$ activity is anti-apoptotic [64]. SMAD-independent pathway may be also activated by endoglins, beta-glucans, as well as an unspecified protein with phosphatidylinositol bindings showing coreceptor features.

\section{Regulation of gene transcription}

Regulation of TGF- $\beta$ gene transcription starts from the SMAD MH2 domain binding to a heterologous DNA-binding domain, e.g. Gal4p. It signalizes readiness of R-SMAD-Co-SMAD complexes to activate the transcription. SMAD proteins are involved in determining which genes will be activated in response to the TGF- $\beta$ stimulation. Particular molecules of the R-SMAD and Co-SMAD complex are able to bind to the DNA thread through the MH1 domain. The most preferable is the binding to the palindromic sequence GTCTAGAC, although to initiate the process, the 
Table 2. SMADs interact with DNA-binding cofactors to specify TGF- $\beta$ gene responses

\begin{tabular}{|c|c|c|c|c|c|c|}
\hline Ligand & Receptor II & Receptor I & SMAD & Co-factor & Target GEN & Response \\
\hline TGF- $\beta$ & TGFR-II & TGFR-II & $\begin{array}{c}\text { SMAD2 } \\
\text { SMAD3 } \\
+ \text { Co-SMAD } 4\end{array}$ & FAST & $\begin{array}{c}\text { Mix.2 } \\
\text { Goosecoid } \\
\text { Nodal.lefty2 }\end{array}$ & $\begin{array}{l}\text { Mesoderm differentiation via Nodal in Xenopus } \\
\text { Mesoderm induction and formation via Nodal } \\
\text { proteins in mice }\end{array}$ \\
\hline \multirow[t]{2}{*}{ Activins } & ActR-II & ActR-I & & TFE3 & $P A l-1$ & $\begin{array}{l}\text { Activation of platelet activating factor and pla- } \\
\text { sminogen, remodelling of the extracellular matrix }\end{array}$ \\
\hline & ActR-IIB & ALK7 & & $\begin{array}{c}\text { SAC } \\
-----\end{array}$ & $\begin{array}{l}\text { Ca1 } \\
\text { Ca2 }\end{array}$ & Immunoglobulin IgA class switching via $\operatorname{TGF} \beta$ \\
\hline Nodal & & & & AP-1 & $\begin{array}{l}\text { C-Jun } \\
\text { C-Fos } \\
\text { ATF-2 }\end{array}$ & Modulation of the response to $\operatorname{TGF} \beta$ \\
\hline BMP2 & BMPR-II & BMPR-IA & SMAD1 & CBFA1 & Osteocalcin? & Osteoblast differentiation via BMP \\
\hline BMP7 & $\begin{array}{l}\text { ActR-II } \\
\text { ActR-IIB }\end{array}$ & BMPR-IB & $\begin{array}{l}\text { SMAD5 } \\
\text { SMAD8 }\end{array}$ & & & \\
\hline GDF5 & & ALK2 & + Co-SMAD 4 & Others & Others & Mesoderm and endoderm induction and diffe- \\
\hline$?$ & $?$ & ALK1 & & & & rentiation in Drosophila \\
\hline
\end{tabular}

binding to AGAC is sufficient. These sites are called Smad-binding elements (SBE) [52]. They are frequently identified in respective regions for TGF- $\beta$ genes, activins, and BMP. In a few genes, the ability to react to signals requires the presence of at least one SBE. However, it is not necessary for each SMAD subunit to be bound to DNA.

The GTCTAGAC sequence, present within SBE, occurs on average once per 1024 pairs of bases in the genome or there is one such place in the regulated region of each gene of a moderate size [65]. Three mechanisms of transcription regulation have been described in the literature:

1) binding of the active R-SMAD-Co-SMAD complex to the transcription factor and next the binding of this multifactorial complex to the recognized DNA sequence;

2) separate binding of SMAD and cofactor to DNA, next the interaction of these proteins and stabilization of enhanced properties;

3) separate binding of SMAD and an additional factor to a definite DNA site - separate but synergistic activity.

SMAD proteins combined with respective DNA receptors and cofactors form specific complexes with a high affinity to DNA. These complexes determine which target genes undergo transcription and to which response pathway they will be directed. SMAD proteins constitute the link of signalling pathways for the following molecules: transforming growth factor $\beta$ (TGF- $\beta$ ), activins, Nodal proteins, bone morphogenetic proteins (BMP2, 7), and growth differentiation factor (GDF5) [66].

The most strongly activated gene in the TGF- $\beta$ transcriptome is $P A I-1$ gene, whose main activator is at the same time the transforming growth factor TGF- $\beta$. Physiologically, phenomena of cell migration and remodelling of the extracellular matrix described for the plasminogen activator inhibitor (PAI-1) depend on TGF- $\beta$ activity. In pathological processes, an elevated TGF- $\beta$ level positively correlates with an increase in the PAI-1 inhibitor level. The extracellular matrix (ECM) is made up of collagens, glycoproteins, proteoglycans and glycosaminoglycans. ECM, to properly play its function, must be continuously remodelled, with the involvement of PAI-1 and PAI-2 factors as well as a thrombin activatable fibrinolysis inhibitor (TAFI) [67]. In to date studies, an increase in the PAI-1 serum level and TAFI activity has been stated in patients with mild and moderate asthma, who have not been treated before [68]. Current studies indicate an elevated PAI-1 serum level in patients with allergic asthma after the challenge with a particular allergen (most frequently home dust mites), as compared to healthy subjects. A higher PAI-1 level positively correlated with a degree of hyper-responsiveness [69]. Activation of the plasma coagulation cascade is associated with activation of blood platelets. Inflammation of bronchial 
mucosa in asthma causes an enhanced inflow of activated mast cells, eosinophils, T lymphocytes, and blood platelets [70]. On the thrombocyte surface, there are receptors of high and low affinity for IgE - the main immunoglobulin involved in the inflammatory reaction in asthma. It has been found that in patients with asthma, the number of IgE-binding platelets increases up to $50 \%$ in comparison with healthy subjects. After the provocation with specific allergens, a few-fold increase in blood platelet accumulation in bronchial vessels is observed [71]. Experimental studies on mice indicated the involvement of blood platelets, both in an initial and in a later phase of immediate hypersensitive reaction. This implies that blood platelets may also actively participate in the process of inflammation and remodelling in humans. A greater number of reticular platelets has been found in the group of patients with allergic asthma as compared to healthy subjects, which demonstrates increased megakaryocytopoiesis [72]. Platelets are a source of inflammatory mediators, such as platelet factor (PF-4), regulated on activation normal t-cell expressed and secreted cytokine (RANTES), platelet-derived growth factor (PDGF), main basic protein (MBP), platelet-activating factor (PAF), and P-selectin [73]. The presented data may suggest a significant role of blood platelets in the development of allergy and asthma, however further detailed studies are required in this subject [74, 75].

During the immune response in the mature plasma cell, the change in the class of synthesized antibodies takes place, which enables the production of various classes and subclasses of immunoglobulins, maintaining the same specificity. This phenomenon is possible due to the recombination between switch regions, which are found in an intron, above exons for stable domains of the immunoglobulin molecule heavy chain. IgA molecule synthesis usually occurs as a result of switching from IgM. The change in synthesized isotope de novo is also possible. This causes a transcription of the gene for the heavy-chain constant region, whose expression is to be altered. The site of the transcription initiation is in "exon I" above each $S$ region. $S \mu / S \alpha$ fragments are formed in the process of recombination determining the change in synthesized antibody classes towards IgA [76]. TGF- $\beta 1$ is a key mediator within the IgA subclass. It induces the transcription of $C \alpha 1$ and $C \alpha 2$ genes in B lymphocytes. TGF- $\beta 1$ inhibits the expression of remaining isotopes, while TGF- $\beta 1$ induces the expression of $\mathrm{I} \alpha 1-\mathrm{C} \alpha 1$ transcripts. The whole process can be enhanced through the stimulation with the independent mitogen, Staphylococcus aureus Cowan 1 (SAC). The I $\alpha 2-\mathrm{C} \alpha 2$ segment does not require additional stimulators of B lymphocytes and is transcribed only in the presence of TGF- $\beta 1$ [77]. The conducted studies have revealed that in subjects with isolated deficit of IgA [78], a lowered number of $S \mu / S \alpha$ fragments and a decreased mRNA expression for $\mathrm{I} \alpha-\mathrm{C} \alpha$ are observed in the examination of peripheral blood mononuclear cells (PBMC). This implies the presence of a defect at the level of class switching in patients with deficiency of this immunoglobulin. Moreover, a reduced TGF- $\beta 1$ level is found in serum of these patients. This suggests that the impaired synthesis of this cytokine, its defective activation, abnormal transmission by the SMAD system and in consequence an improper expression of the TGFR receptor on target cells may have an effect on formation of selective IgA deficit as well as other diseases based on deficiency of this immunoglobulin [77]. Selective IgA deficiency (sIgAD) is one of the factors worsening prognosis in asthma. Co-occurrence of both diseases has been observed in a certain group of patients. In patients with a positive history of asthma, an increased frequency of the diagnosis of selective IgA deficit and common variable immunodeficiency (CVID) has been noted [79]. Due to some difficulties in defining the precise time of the disease onset and asymptomatic development of IgA deficit, it was not possible to determine which impairment is the first one to occur [80]. IgA deficits, with the presence of an elevated or stable IgE level, are commonly detected in allergic diseases and bronchial asthma. There are some studies that indicated a decrease in the IgA level in serum of patients with bronchial hyper-responsiveness and evident atopy in skin prick tests (SPT). It was also observed that the level of immunoglobulins negatively correlated with the intensity of symptoms in asthma patients. The following immunoglobulin profile is most often encountered: $\uparrow$ IgE, IgM stable, IgA stable or $\downarrow$, IgG stable or $\downarrow$ IgG2. Although the constitutive levels of both immunoglobulins, IgA and IgG, are usually below normal range, only the IgA level correlates with severity of disease symptoms the lower the level the more severe symptoms are [81]. Apart from susceptibility to atopy, frequent infections are one of the factors exacerbating the course of asthma and enhancing inflammatory reactions in the respiratory tract. In an antiviral response, a key role is played by Th2 lymphocytes whose function is among others to secrete Il-6 stimulating IgA production on the surface 
of bronchial and alimentary tract mucosa. IgA deficit, an impaired expression, synthesis, and induction of this immunoglobulin cause a decrease in efficiency of the immune system related to the mucosa-associated lymphoid tissues (MALT). A more severe course of infection leads to exacerbation of the primary disease and its worse control. Similar values were observed in children with an elevated level of IgA, independent from IgE, in the study evaluating the prevalence of infections in a paediatric population. The conclusion was drawn that the deficit of this immunoglobulin is more important in the occurrence of recurrent infections in children than atopy [82]. The effect of TGF- $\beta$ on the signalling pathway and switching of immunoglobulin classes can also influence the occurrence of IgA deficiency and cause more severe course of the disease, exacerbations, and worse asthma control.

The TGF- $\beta$ factor activates the activating protein-1 transcription complex (APC) through the SMAD signalling pathway. There are three families of transcription proteins within this complex - the family of Fos proteins (c-Fos, FosB, Fra1, Fra2), Jun proteins (c-Jun, JunB, JunD) and activating transcription factors (ATFa, ATF2, ATF3, ATF4 and B-ATF) [83]. Jun and Fos proteins form complexes which play a key role in inducing inflammation in asthma. Jun/Jun homodimers are less stable and less capable of binding to DNA. Fos/Jun heterodimers are more stable complexes characterized by a higher affinity for DNA [84]. The Jun/Fos complex activates and regulates genes subject to overexpression in asthma, especially severe asthma. Active AP-1 directly reacts to the glucocorticoid receptor, which has a great impact on asthma control and its steroid-resistant form. Conducted observations have proven an increase in activity of AP-1 transcription complex in the respiratory mucosa after the exposition to PMA (forbol ester, capable of activating protein kinase C), tumour necrosis factor $\alpha$ (TNF- $\alpha$ ) and IL-1 $\beta$ interleukin as well as in the peripheral blood mononuclear cells after PMA stimulation. Further observations indicated an increase in the expression of c-fos and c-jun transcription factors resulting in an elevated level of c-Fos and c-Jun proteins, being the product of these genes activation [85]. Moreover, an increase in the activity of c-Jun N-terminal kinases leading to the enhancement of the cell response to proinflammatory cytokines was also noted. In the respiratory tract of asthma patients, a constitutive increase in the c-Fos expression was found [86]. An active complex AP- 1 is necessary to differentiate native T lymphocytes to Th1 and Th2 fraction, which play a special role in the T-cell dependent immune response. Th2 lymphocytes, affected by AP-1, secrete proinflammatory factors such as IL4, IL-5 and IL-15. Moreover, the AP-1 transcription complex activated by TGF- $\beta$ activates genes of the matrix metalloproteinase (MMP)-1, MMP-3, and MMP-9 inducing the matrix decomposition and remodelling. Transcription of proinflammatory cytokines, such as IL-1 and IL-2 as well as iterferon gamma (IFN- $\gamma$ ), is activated through the AP-1 factor and suppressed by the glucocorticoid receptor (GR) [87]. Repression of the proinflammatory gene activity by glucocorticosteroids is possible due to vicinity of the glucocorticoid response element (GRE) and the AP-1 transcription factor adjacent to the DNA promoter region. Then the GR receptor interacts with the c-Jun protein, which directly leads to the repression of genes [88]. Another way of inhibiting the gene expression by the GR receptor is the so called crosstalk mechanism (i.e. protein-protein interaction) depending on the interaction with transcription factors, such as $\mathrm{NF} \kappa \mathrm{B}$, AP-1, NFAT, or STAT [89]. Indirect interaction through transcription proteins is the main mechanism regulating the immune response through glucocorticosteroids. They bind to the GR receptor and act as an anti-inflammatory agent reducing AP-1 production and increasing the $\mathrm{NF} \kappa \mathrm{B}$ inhibitory protein $(\mathrm{I} \kappa \mathrm{Ba}$ - nuclear factor of kappa light polypeptide gene enhancer in B-cells inhibitor). In asthma patients, an increased constitutive level of the AP-1 transcription factor is observed [90]. This causes binding of the AP-1 complex to the GR receptor, preventing glucocorticosteroids from binding to the glucocorticoid response element (GRE) and from inhibiting the AP-1 synthesis. This has been evidenced in the study on two groups of patients who were either corticosteroid-sensitive or -resistant. In the latter group, a few-fold higher level of the proinflammatory c-fos AP-1 unit was detected as compared to patients sensitive to treatment with inhaled and/or systemic steroids. A similar phenomenon of steroid-resistance is observed in such pathological states as rheumatoid arthritis, leukemia, and graft rejection [91].

\section{Tgf-smad signalling pathway in selected pulmonary diseases}

Transforming Growth factor $\beta$ is also involved in fibrosis and airway remodelling in chronic obstructive pulmonary disease (COPD) [92]. The TGF $\beta$ level in primary cells, epithelial cells, ma- 
crophages, fibroblasts isolated from COPD-lungs has increased, that may suggest an impact of TGF $\beta$ signalling has an impact on the proccess of progression of COPD [93]. In addition, several studies have reported elevated TGF- $\beta 1$ expression in the airway epithelium in patients with COPD or chronic bronchitis, as well as smokers [21].

The TGF- $\beta$ signalling pathway may also be involved is idiopathic pulmonary fibrosis (IFP), in which a crucial role is played by epithelialmesenchymal transition (EMT) [94]. EMT is a process whereby differentiated epithelial cells transform into mesenchymal phenotype, which can then differentiate into fibroblasts and myofibroblasts [95]. TGF- $\beta$ is a hard inductor of fibrogenesis, as well as a major mediator of EMT via SMAD-dependent pathway [96, 97].

Furthermore, TGF-SMAD molecular pathway is involved in pathogenesis of primary pulmonary hypertension (PPH) [98, 99]. Some studies indicate, that pulmonary artery smooth muscle cells (PASMCs) from patients with PPH exhibit abnormal growth responses to TGF- $\beta$ superfamily members [100]. It is postulated that BMPR2 mutation may disrupt the entire TGF-SMAD signalling pathway, resulting in hypertrophy and hyperplasia of vascular smooth muscle and endothelial cells [101].

\section{Summary}

A TGF- $\beta$ factor is evidently one of the main cytokines involved in mediating inflammation and remodelling processes in bronchial airways [1]. The main pathway of signal transmission via TGF- $\beta$ occurs with the interaction of the SMAD proteins. The knowledge of the transmission pathway and the processes of gene transcription determining variety of response induced by this cytokine allows clinicians to evaluate immune reactions in patients.

Further cognitive and practical studies may form the basis for creation of specific biological therapy. Designing peptide and protein inhibitors of the TGF- $\beta$ receptor, selective for TGF- $\beta 1$, may in future offer hope for patients with severe asthma.

\section{Conflict of interest:}

The authors declare no conflict of interest.

\section{References:}

1. 1.Govinden R, Bhoola KD. Genealogy, expression, and cellular function of transforming growth factor-beta. Pharmacol Ther. 2003; 98: 257-265.

2. Wu MY, Hill CS. TGF- $\beta$ Superfamily Signaling in Embryonic Development and Homeostasis. Developmental Cell. 2009; 16: $329-343$.
3. Weiss A, Attisano L. The TGFbeta superfamily signaling pathway. Wiley Interdiscip Rev Dev Biol. 2013; 2: 47-63.

4. Stepień-Wyrobiec O, Hrycek A, Wyrobiec G. Transforming growth factor beta (TGF-beta): its structure, function, and role in the pathogenesis of systemic lupus erythematosus. Postepy Hig Med Dosw. 2008; 62: 688-693.

5. Dijke ten P, Geurts van Kessel AH, Foulkes JG, Le Beau MM. Transforming growth factor type beta 3 maps to human chromosome 14, region q23-q24. Oncogene. 1988; 3: 721-724.

6. Santibanez JF, Kocic J. Transforming growth factor- $\beta$ superfamily, implications in development and differentiation of stem cells. Biomol Concepts. 2012; 3: 429-445.

7. Santibanez JF. Transforming growth factor-beta and urokinase -type plasminogen activator: dangerous partners in tumorigenesis-implications in skin cancer. ISRN Dermatology. Hindawi Publishing Corporation 2013; 597927: 1-26.

8. Govinden R, Bhoola KD. Genealogy, expression, and cellular function of transforming growth factor-beta. Pharmacol Ther. 2003; 98: 257-265.

9. Leask A, Abraham DJ. TGF-beta signaling and the fibrotic response. FASEB J. 2004; 18: 816-827.

10. Unsöld C, Hyytiäinen M, Bruckner-Tuderman L, Keski-Oja J. Latent TGF-beta binding protein LTBP-1 contains three potential extracellular matrix interacting domains. J Cell Sci. 2001; 114: 187-197.

11. Talar B, Czyż M. Rola szlaków sygnałowych TGF- $\beta$ w nowotworach. Postepy Hig Med Dosw (Online). 2013; 67: 1008-1017.

12. Moldoveanu B, Otmishi P, Jani P et al. Inflammatory mechanisms in the lung. J Inflammation Res 2009; 2: 1-11.

13. Dobolyi A, Vincze C, Pál G, Lovas G. The Neuroprotective functions of transforming growth factor beta proteins. International Journal of Molecular Sciences. Multidisciplinary Digital Publishing Institute (MDPI); 2012; 13: 8219-8258.

14. Makinde T, Murphy RF, Agrawal DK. The regulatory role of TGF-beta in airway remodeling in asthma. Immunol Cell Biol. 2007; 85: 348-356.

15. Metawie SA, ElRefai RM, ElAdle SS, Shahin RMH. Transforming growth factor- $\beta 1$ in systemic lupus erythematosus patients and its relation to organ damage and disease activity. The Egyptian Rheumatologist 2015; 37: 49-54.

16. Viswanath V, Phiske MM, Gopalani VV. Systemic sclerosis: current concepts in pathogenesis and therapeutic aspects of dermatological manifestations. Indian J Dermatol 2013; 58: 255-268.

17. Krzemień S. Current review on the role of transforming growth factor beta (TGF-beta) in some pathological disorders. Wiad Lek 2005; 58: 536-539.

18. Bossé Y, Rola-Pleszczynski M. Controversy surrounding the increased expression of TGF $\beta 1$ in asthma. Respiratory Research 2008 9:1. BioMed Central; 2007; 8: 1.

19. Manuyakorn W, Kamchaisatian W, Atamasirikul K, Sasisakulporn C, Direkwattanachai C, Benjaponpitak S. Serum TGF -beta1 in atopic asthma. Asian Pac J Allergy Immunol 2008; 26: 185-189.

20. Minshall EM, Leung DYM, Martin RJ et al. EosinophIL-associated TGF- $\beta$ 1mRNA Expression and Airways Fibrosis in Bronchial Asthma. Am J Respir Cell Mol Biol. American Thoracic Society New York, NY; 1997; 17: 326-333.

21. Takizawa $H$, Tanaka M, Takami K et al. Increased expression of transforming growth factor-beta1 in small airway epithelium from tobacco smokers and patients with chronic obstructive pulmonary disease (COPD). Am J Respir Crit Care Med 2001; 163: 1476-1483.

22. Halwani R, Al.-Muhsen S, Al.-Jahdali H, Hamid Q. Role of transforming growth factor- $\beta$ in airway remodeling in asthma. Am J Respir Cell Mol Biol 2011; 44: 127-133.

23. Panek M, Pietras T, Szemraj J, Fabijan A, Kuna P. Identification and association of TGF $\beta-1$ expression in patients with asthma in a Polish population — Lodz metropolitan area study. International Journal of Biochemistry and Molecular Biology. e-Century Publishing Corporation 2013; 4: 67-74.

24. Jonakowski M, Zioło J, Koćwin M et al. A step further to understand the role of IL-15 in modulation of TGF- $\beta 1$-mediated inflammation in asthma. Mediators of Inflammation 2016; 1-20.

25. Silverman ES, Palmer LJ, Subramaniam V et al. Transforming Growth Factor- $\beta$ 1Promoter Polymorphism C-509T Is Asso- 
ciated with Asthma. Am J Respir Crit Care Med. American Thoracic Society 2004; 169: 214-219.

26. Pulleyn LJ, Newton R, Adcock IM, Barnes PJ. TGFbeta1 allele association with asthma severity. Hum Genet 2001; 109: 623-627.

27. Panek M, Pietras T, Fabijan A et al. Identification and association of the single nucleotide polymorphisms, C-509T, C+466T and $\mathrm{T}+869 \mathrm{C}$, of the TGF- $\beta 1$ gene in patients with asthma and their influence on the mRNA expression level of TGF- $\beta 1$. Int J Mol Med 2014; 34: 975-986.

28. de Guia RM, Ramos JDA. The -590C/TIL4 single-nucleotide polymorphism as a genetic factor of atopic allergy. International Journal of Molecular Epidemiology and Genetics. e-Century Publishing Corporation; 2010; 1: 67-73.

29. Gatherer D, Dijke ten P, Baird DT, Akhurst RJ. Expression of TGF-beta isoforms during first trimester human embryogenesis. Development 1990; 110: 445-460.

30. Epstein FH, Blobe GC, Schiemann WP, Lodish HF. Role of transforming growth factor $\beta$ in human disease. N Engl J Med 2000; 342: 1350-1358.

31. Lutty GA, Merges C, Threlkeld AB, Crone S, McLeod DS. Heterogeneity in localization of isoforms of TGF-beta in human retina, vitreous, and choroid. Invest Ophthalmol Vis Sci 1993; 34: 477-487.

32. Unsicker K, Strelau J. Functions of transforming growth factor-beta isoforms in the nervous system. Cues based on localization and experimental in vitro and in vivo evidence. Eur J Biochem. 2000; 267: 6972-6975.

33. Heupel K, Sargsyan V, Plomp JJ et al. Loss of transforming growth factor-beta 2 leads to impairment of central synapse function. Neural Dev 2008; 3: 25.

34. Bottoms SE, Howell JE, Reinhardt AK, Evans IC, McAnulty RJ. Tgf-Beta isoform specific regulation of airway inflammation and remodelling in a murine model of asthma. PLoS ONE. 2010; 5: e9674.

35. Czarniakowska-Bołtuć M, Ziętkowski Z, Bodzenta-Łukaszyk A. Role of selected growth factors in asthma. Alergia Astma Immunolgia 2012; 17: 172-179.

36. Boxall C, Holgate ST, Davies DE. The contribution of transforming growth factor-beta and epidermal growth factor signalling to airway remodelling in chronic asthma. Eur Respir J 2006; 27: 208-229.

37. Chu HW, Balzar S, Seedorf GJ et al. Transforming growth factor- $\beta 2$ induces bronchial epithelial mucin expression in asthma. Am J Pathol. American Society for Investigative Pathology 2004; 165: 1097-1106.

38. Torrego A, Hew M, Oates T, Sukkar M, Fan Chung K. Expression and activation of TGF-beta isoforms in acute allergen-induced remodelling in asthma. Thorax 2007; 62: 307-313.

39. Dobaczewski M, Chen W, Frangogiannis NG. Transforming growth factor (TGF) $\beta$ signaling in cardiac remodeling. J Mol Cell Cardiol 201; 51: 600-606.

40. Wadhwa M, Dilger P, Hamill M et al. The $1^{\text {st }}$ International standard for transforming growth factor- $\beta 3$ (TGF- $\beta 3$ ). J Immunol Methods 2012; 380: 1-9.

41. Kandasamy M, Lehner B, Kraus S et al. TGF-beta signalling in the adult neurogenic niche promotes stem cell quiescence as well as generation of new neurons. J Cell Mol Med 2014; 18 : 1444-1459.

42. Millan FA, Denhez F, Kondaiah P, Akhurst RJ. Embryonic gene expression patterns of TGF beta 1, beta 2 and beta 3 suggest different developmental functions in vivo. Development 1991; 111: 131-143.

43. Massagué J, Seoane J, Wotton D. Smad transcription factors. Genes Dev 2005; 19: 2783-2810.

44. Witkowska M, Smolewski P. Białka z rodziny SMAD: współczesna wiedza na temat ich ekspresji i potencjalnej roli w chorobach nowotworowych. Postepy Hig Med Dosw 2014; 68: 301-309.

45. Gaarenstroom T, Hill CS. TGF- $\beta$ signaling to chromatin: how Smads regulate transcription during self-renewal and differentiation. Semin Cell Dev Biol 2014; 32: 107-118.

46. Armes NA, Smith JC. The ALK-2 and ALK-4 activin receptors transduce distinct mesoderm-inducing signals during early Xenopus development but do not co-operate to establish thresholds. Development 1997; 124: 3797-3804.
47. Dudas M, Nagy A, Laping NJ, Moustakas A, Kaartinen V. Tg -beta3-induced palatal fusion is mediated by Alk-5/Smad pathway. Dev Biol 2004; 266: 96-108.

48. Miyazono K, Maeda S, Imamura T. BMP receptor signaling: transcriptional targets, regulation of signals, and signaling cross-talk. Cytokine Growth Factor Rev 2005; 16: 251-263.

49. Shi Y, Massagué J. Mechanisms of TGF-beta signaling from cell membrane to the nucleus. Cell 2003; 113: 685-700.

50. Boesen CC, Radaev S, Motyka SA, Patamawenu A, Sun PD. The 1.1 A crystal structure of human TGF-beta type II receptor ligand binding domain. Structure 2002; 10: 913-919.

51. Allendorph GP, Read JD, Kawakami Y, Kelber JA, Isaacs MJ, Choe S. Designer TGF $\beta$ superfamily ligands with diversified functionality. Mitraki A. (ed.). PLoS ONE. Public Library of Science 2011; 6:e26402.

52. Massagué J, Wotton D. Transcriptional control by the TGF-beta/ Smad signaling system. EMBO J 2000; 19: 1745-1754.

53. Schiller M, Javelaud D, Mauviel A. TGF-beta-induced SMAD signaling and gene regulation: consequences for extracellular matrix remodeling and wound healing. J Dermatol Sci 2004; 35: 83-92.

54. Heldin C-H, Moustakas A. Role of Smads in TGF $\beta$ signaling. Cell Tissue Res 2012; 347: 21-36.

55. Massagué J. TGF $\beta$ signalling in context. Nat Rev Mol Cell Biol 2012; 13: 616-630.

56. Haery L, Thompson RC, Gilmore TD. Histone acetyltransferases and histone deacetylases in B- and T-cell development, physiology and malignancy. Genes Cancer 2015; 6: 184-213.

57. Allen DL, Unterman TG. Regulation of myostatin expression and myoblast differentiation by FoxO and SMAD transcription factors. AJP: Cell Physiology. 2006; 292: 188-199.

58. Itoh S, Dijke ten P. Negative regulation of TGF-beta receptor/Smad signal transduction. Curr Opin Cell Biol 2007; 19: 176-184.

59. Shi Y, Massagué J. Mechanisms of TGF-beta signaling from cell membrane to the nucleus. Cell 2003; 113: 685-700.

60. Ohashi N, Yamamoto T, Uchida C et al. Transcriptional induction of Smurf2 ubiquitin ligase by TGF-beta. FEBS Lett 2005; 579: 2557-2563

61. Boone B, Haspeslagh M, Brochez L. Clinical significance of the expression of c-Ski and SnoN, possible mediators in TGF-beta resistance, in primary cutaneous melanoma. J Dermatol Sci 2009; 53: 26-33.

62. Siegel PM, Massagué J. Cytostatic and apoptotic actions of TGF-beta in homeostasis and cancer. Nat Rev Cancer 2003; 3: 807-821.

63. Siegel PM, Massagué J. Cytostatic and apoptotic actions of TGF-beta in homeostasis and cancer. Nat Rev Cancer 2003; 3: 807-821.

64. Gingery A, Bradley EW, Pederson L, Ruan M, Horwood NJ, Oursler MJ. TGF- $\beta$ coordinately activates TAK1/MEK/AKT/ NFkB and SMAD pathways to promote osteoclast survival. Experimental Cell Research 2008; 314: 2725-2538.

65. Manfredi M. Hereditary hamartomatous polyposis syndromes: understanding the disease risks as children reach adulthood. Gastroenterol Hepatol 2010; 6: 185-233.

66. Massagué J. How cells read TGF-beta signals. Nat Rev Mol Cell Biol 2000; 1: 169-178.

67. Wyrzykowska P, Kasza A. Regulation of PAI-1 expression. Postepy Biochem 2009; 55: 46-53.

68. Kemona-Chętnik I, Kowal K, Kucharwicz I. Aktywowany trombiną inhibitor fibrynolizy (TAFI) w astmie alergiczej. Przegląd Lekarski 63: 1281-1285.

69. Kowal K, Bodzenta-Lukaszyk A, Pampuch A, Szmitkowski M, Donati MB, Iacoviello L. Plasminogen Activator Inhibitor-1 Plasma Concentration in Allergic Asthma Patients during Allergen Challenge. Int Arch Allergy Immunol 2007; 144: 240246.

70. Bodzenta-Lukaszyk A. Platelets. Alergia Astma Immunologia 2005; 10: 16-18.

71. Kowal K, Pampuch A, Kowal-Bielecka O, DuBuske LM, Bodzenta-Lukaszyk A. Platelet activation in allergic asthma patients during allergen challenge with Dermatophagoides pteronyssinus. Clin Exp Allergy 2006; 36: 426-432. 
72. Kemona-Chętnik I, Bodzenta-Lukaszyk A, Butkiewicz A, Dymnicka-Piekarska V, Kemona H. Trombocytopoeza u chorych na astme alergiczna. 2007; 117: 9-13.

73. Kasperska-Zajac A, Rogala B. Platelet activation during allergic inflammation. Inflammation 2007; 30: 161-166.

74. Stoll P, Lommatzsch M. Platelets in asthma: does size matter? Respiration 2014; 88: 22-33.

75. Page C, Pitchford S. Platelets and allergic inflammation. Clin. Exp. Allergy 2014; 44: 901-913.

76. Cameron L, Gounni AS, Frenkiel S, Lavigne F, Vercelli D, Hamid Q. S epsilon S mu and S epsilon S gamma switch circles in human nasal mucosa following ex vivo allergen challenge: evidence for direct as well as sequential class switch recombination. J Immunol 2003; 171: 3816-3822.

77. Yel L. Selective IgA deficiency. J Clin Immunol 2010; 30: 10-16.

78. Islam KB, Baskin B, Nilsson L, Hammarström L, Sideras P, Smith CI. Molecular analysis of IgA deficiency. Evidence for impaired switching to IgA. J Immunol. 1994; 152: 1442-1452.

79. Urm S-H, Yun HD, Fenta YA, et al. Asthma and risk of selective iga deficiency or common variable immunodeficiency: a population-based case-control study. Mayo Clinic Proceedings 2013; 88: 813-821.

80. Papadopoulou A, Mermiri D, Taousani S, Triga M, Nicolaidou P, Priftis KN. Bronchial hyper-responsiveness in selective IgA deficiency. Pediatr Allergy Immunol 2005;16: 495-500.

81. Balzar S, Strand M, Nakano T, Wenzel SE. Subtle immunodeficiency in severe asthma: IgA and IgG2 correlate with lung function and symptoms. Int Arch Allergy Immunol 2006; 140: 96-102.

82. Fuchs SI, Gappa M. Lung clearance index: clinical and research applications in children. Paediatric Respiratory Reviews 2011; 12: 264-270.

83. Gustems M, Woellmer A, Rothbauer U et al. c-Jun/c-Fos heterodimers regulate cellular genes via a newly identified class of methylated DNA sequence motifs. Nucleic Acids Research 2014; 42: 3059-3072.

84. Głobińska A. Natural immunological response to respiratory viruses - intracellular signalling pathway sygnałowe. Alergia Astma Immunologia 2012; 17: 66-76.

85. Barnes PJ, Adcock IM. Transcription factors and asthma. Eur Respir J 1998; 12: 221-234.

86. Karin M, Liu ZG, Zandi E. AP-1 function and regulation. Curr Opin Cell Biol 1997; 9: 240-246.

87. Panek M, Pietras T, Fabijan A et al. The NR3C1 glucocorticoid receptor gene polymorphisms may modulate the TGF-beta mRNA expression in asthma patients. Inflammation 2015; 38 : 1479-1492.

88. Necela BM, Cidlowski JA. Mechanisms of glucocorticoid receptor action in noninflammatory and inflammatory cells. proceedings of the American Thoracic Society. American Thoracic Society 2012; 1: 239-246.

89. Panek M, Pietras T, Fabijan A et al. The NR3C1 glucocorticoid receptor gene polymorphisms may modulate the TGF-beta mRNA expression in asthma patients. Inflammation 2015; 38: 1479-1492.

90. Adcock IM, Lane SJ, Brown CR, Lee TH, Barnes PJ. Abnormal glucocorticoid receptor-activator protein 1 interaction in steroid-resistant asthma. Journal of Experimental Medicine. 1995; 182: 1951-1958.

91. Papadopoulou A, Mermiri D, Taousani S, Triga M, Nicolaidou P, Priftis KN. Bronchial hyper responsiveness in selective IgA deficiency. Pediatric Allergy and Immunology 2005; 16: 495-500.

92. Springer J, Scholz FR, Peiser C, Groneberg DA, Fischer A. SMAD-signaling in chronic obstructive pulmonary disease: transcriptional down-regulation of inhibitory SMAD 6 and 7 by cigarette smoke. Biological ChemistrY 2004; 385: 649-653.

93. Königshoff M, Kneidinger N, Eickelberg O. TGF-beta signaling in COPD: deciphering genetic and cellular susceptibilities for future therapeutic regimen. Swiss Med Wkly 2009; 139: 554-563.

94. Moisés Selman AP. Idiopathic pulmonary fibrosis: an epithelial/fibroblastic cross-talk disorder. Respiratory Research 2008 9:1. BioMed Central 2002; 3: 3.

95. Noble PW, Homer RJ. Idiopathic pulmonary fibrosis: new insights into pathogenesis. Clinics in Chest Medicine 2004; 25: 749-758.

96. Willis BC, Borok Z. TGF-beta-induced EMT: mechanisms and implications for fibrotic lung disease. Am J Physiol Lung Cell Mol Physiol 2007; 293: 525-534.

97. Kasai H, Allen JT, Mason RM, Kamimura T, Zhang Z. TGF- $\beta 1$ induces human alveolar epithelial to mesenchymal cell transition (EMT). Respiratory Research 2008 9:1. BioMed Central 2005; 6: 56.

98. Yang X. Dysfunctional smad signaling contributes to abnormal smooth muscle cell proliferation in familial pulmonary arterial hypertension. Circulation Research 2005; 96: 1053-1063.

99. Simonneau G, Gatzoulis MA, Adatia I et al. Updated clinical classification of pulmonary hypertension. J Am Coll Cardiol 2013; 62: 34-41.

100.Rudarakanchana N, Flanagan JA, Chen $\mathrm{H}$ et al. Functional analysis of bone morphogenetic protein type II receptor mutations underlying primary pulmonary hypertension. Hum Mol Genet 2002; 11: 1517-1525.

101. Morrell NW, Yang X, Upton PD et al. Altered growth responses of pulmonary artery smooth muscle cells from patients with primary pulmonary hypertension to transforming growth factor-beta(1) and bone morphogenetic proteins. Circulation 2001; 104: 790-795. 